\title{
RELASI AGAMA DAN NEGARA DALAM PERSPEKTIF ISLAM
}

\author{
Zaprulkhan \\ STAIN Syaikh Abdurrahman Siddik Bangka Belitung \\ e-mail: zaprulkhan_zahra@yahoo.co.id
}

\begin{abstract}
One discourse that continues to be discussed in the realm of Islamic political philosophy is about the relation between religion and state. Broadly speaking, there are at least three paradigms of thinking about the relationship between religion and state. First, sekularistik paradigm, which says that Islam has nothing to do with the state, because Islam does not regulate state life or reign. Second, formalistic paradigm, which assumes that Islam is a complete religion, which includes everything, including the question of the state or a political system. Third, paradigms substansialistik, which rejects the notion that Islam covers everything and also rejects the notion that Islam is only governs the relationship between man and his Creator alone. This article will take pictures of how the three views of this paradigm by showing some of the characters are representative and critically using the comparative method.
\end{abstract}

Salah satu wacana yang terus diperbincangkan dalam ranah filsafat politik Islam adalah mengenai relasi antara agama dan negara. Secara garis besar paling tidak ada tiga paradigma pemikiran tentang hubungan agama dan negara. Pertama, paradigma sekularistik, yang mengatakan bahwa Islam tidak ada hubungannya dengan negara, karena Islam tidak mengatur kehidupan bernegara atau pemerintahan. Kedua, paradigma formalistik, yang menganggap bahwa Islam adalah agama yang paripurna, yang mencakup segala-galanya, termasuk masalah negara atau sistem politik. Ketiga, paradigma substansialistik, yang menolak pendapat bahwa Islam mencakup segala-galanya dan juga menolak pandangan bahwa Islam hanya mengatur hubungan antara manusia dan Penciptanya semata. Artikel ini akan memotret bagaimana pandangan ketiga paradigma tersebut dengan menampilkan beberapa tokohnya yang representatif dan dengan menggunakan metode kritis komparatif.

Keywords: politik, Islam, negara, paradigma 


\section{A. Pendahuluan}

Ada satu memori kolektif yang kuat di kalangan umat Islam, yaitu terdapatnya doktrin yang berbunyi al-Islām huwa al-dīn wa 'l-dawlah,1 Islam adalah agama dan sekaligus kekuasaan. Implikasi dari hubungan ini, antara agama dan negara, antara aspek ritual dan politik, sangat erat kaitannya, bahkan tidak bisa dipisahkan. Aspek hukum menyentuh ke semua aspek sosial politik. Sejak Nabi Muhammad sampai sekarang, kenangan tentang Madinah — tempat dimana Nabi mulai memetik kesuksesan dalam dakwah dan membangun masyarakatnya- sangat kuat. ${ }^{2}$

Lazimnya, orang Islam percaya terhadap sifat Islam yang holistik. Sebagai sebuah alat untuk memahami kehidupan, Islam sering dianggap sebagai sesuatu yang lebih dari sekadar agama. Ada yang melihatnya sebagai suatu "masyarakat sipil". Ada juga yang menilainya sebagai suatu sistem "peradaban yang menyeluruh". Bahkan, ada pula yang mempercayainya sebagai "agama dan negara". Lebih spesifik lagi, Islam tidak mengenal dinding pemisah antara yang bersifat spiritual dan temporal. Sebaliknya, Islam memberi panduan etis bagi setiap aspek kehidupan. ${ }^{3}$

Meskipun Islam diyakini memberi pedoman bagi segala aspek kehidupan, khususnya mengenai ketatanegaraan atau politik, ternyata hubungan antara agama dan negara dalam Islam sangat poly interpretable, kaya penafsiran. Dalam Islam, pemikiran politik mengenai hubungan agama dan negara ternyata masih menjadi perdebatan yang hangat di kalangan para ahli. ${ }^{4}$ Secara global, hingga kini setidaknya ada tiga paradigma pemikiran tentang hubungan agama dan negara. ${ }^{5}$ Pertama, paradigma yang mengatakan bahwa Islam tidak ada hubungannya dengan negara, karena Islam tidak mengatur kehidupan bernegara atau pemerintahan. Menurut paradigma ini, secara historis wilayah Nabi Muhammad

\footnotetext{
1Mengenai doktrin ini bisa dilihat dalam Dale F. Eickelman \& James Piscatori, Ekspresi Politik Muslim, terj. RofikSuhud, (Bandung: Mizan, 1998), h. 71-72. 102.

${ }^{2}$ Komaruddin Hidayat, Wahyu di Langit Wahyu di Bumi, (Jakarta: Paramadina, 2003), h. 93, 101-

${ }^{3}$ Bahtiar Effendy, Teologi Baru Politik Islam, (Yogyakarta: Galang Press, 2001), h. 7-8.

${ }^{4}$ Menurut Azra perdebatan tersebut sampai dewasa ini belum juga tuntas, Lihat: Azyumardi Azra, Pergolakan Politik Islam, (Jakarta: Paramadina, 1996), h. 1.

5Munawir Sjadzali, Islam dan Tata Negara, (Jakarta: UI Press, 1993), h. 1-2; Suyuthi Pulungan, Fiqh Siyasah, (Jakarta: Grafindo Persada, 2002), h. x; Tim Puslit IAIN Syarif Hidayatullah, Pendidikan Kewarganagaraan, Demokrasi, HAM dan Masyarakat Madani, Uakarta: IAIN Syarif Hidayatullah Press, 2000), h. 127-128.
} 
terhadap kaum Mukmin adalah wilayah risalah yang tidak dicampuri oleh tendensi pemerintahan. ${ }^{6}$ Sebagian tokoh terkenal yang mendukung konsep ini adalah 'Ali Raziq dan Thaha Husein.

Paradigma kedua menganggap bahwa Islam adalah agama yang paripurna, yang mencakup segala-galanya, termasuk masalah negara atau sistem politik. Tokoh-tokoh utama dari paradigma ini adalah Hassan al-Banna, Sayyid Quthb, Rasyid Ridha dan tentu saja Abu al-A'la al-Maududi.

Paradigma ketiga, menolak pendapat bahwa Islam mencakup segala-galanya dan juga menolak pandangan bahwa Islam hanya mengatur hubungan antara manusia dan Penciptanya semata. Paradigma ini berpendapat bahwa Islam memang tidak mencakup segala-galanya, tapi mencakup seperangkat prinsip dan tata nilai etika tentang kehidupan bermasyarakat termasuk bernegara. Tokoh yang termasyhur dalam paradigma ini adalah Muhammad 'Abduh dan Muhammad Husein Haikal.

Tulisan ini akan memotret bagaimana pandangan ketiga paradigma tersebut dengan menampilkan beberapa tokohnya yang representatif dengan menggunakan metode kritis komparatif. Metode komparatif di sini berusaha membandingkan ketiga paradigma pemikiran politik Islam tersebut untuk kemudian dilakukan suatu analisis evaluatif sekaligus konklusi terhadap ketiga paradigma di atas. ${ }^{7}$

\section{B. Spektrum Wacana Politik Islam}

\section{Paradigma Sekularistik}

'Ali 'Abd al-Raziq menjelaskan pandangannya dengan beberapa prinsip. Pertama, tidak ada sistem khilāfah dalam al-Qur'an dan Sunnah. Menurut Raziq, khilāfah merupakan kepemimpinan umum dalam urusan agama dan dunia menggantikan Nabi SAW. Ibn Khaldun menguraikan pengertian khilāfah secara komprehensif:

"Khiläfah adalah memerintah rakyat sesuai dengan aturan shara', demi kebaikan akhirat mereka dan juga kebaikan dunia yang kembali pada kepentingan akhirat. Sebab menurut shara' persoalan-persoalan dunia semuanya kembali kepada kepentingan akhirat. Khiläfah dengan demikian hakikat-

\footnotetext{
${ }^{6}$ Untuk bacaan lebih luas mengenai wilayah Nabi Muhammad atas kaum Mukmin, Lihat: 'Ali 'Abd al- Raziq, al-Islām wa Ușūl al-Hukm, terj. M. Zaid Su'di, (Yogyakarta: Jendela, 2002), h. 77-94.

${ }^{7}$ Kaelan, Metode Penelitian Kualitatif Bidang Filsafat, (Yogyakarta: Paradigma, 2005), h. 94-95.
} 
nya adalah menggantikan pembuat shara' (sāḥib al-shara') dalam menjaga eksistensi agama dan sistem politik dunia."8

Definisi tersebut mengindikasikan bahwa bagi kaum Muslim, kedudukan seorang khaliffah berada dalam posisi Rasul SAW, yang bukan saja mengurus persoalan agama melainkan juga permasalahan-permasalahan dunia. ${ }^{9}$ Khalifah menjadi representasi dari seorang penguasa agama sekaligus politik dunia. Dengan argumentasi tersebut, menerima sistem kekuasaan khiläfah adalah sebuah kewajiban untuk merealisasikan pesan-pesan agama dan pemerintahan yang memperhatikan kepentingan rakyat.10

'Abd al-Raziq menolak semua alasan di atas. Menurutnya, al-Qur'an tidak mengemukakan persoalan tersebut, selain hanya pernyataan-pernyataan umum agar menghormati mereka yang memegang kekuasaan. Hadits juga tidak mengemukakan pendapat, selain pernyataan umum tentang kepatuhan kepada imam, tanpa satu pun definisi yang jelas mengenai fungsi imam atau pernyataan mengenai keharusannya. Bahkan jika hadits itu benar-benar menunjuk kepada khalïfah ketika mengatakan tentang imam, hal ini tidak mengisyaratkan bahwa harus selalu ada seorang khalifah. ${ }^{11}$

Sejarah Islam hampir tidak mengenal adanya khalifah melainkan di sana bercokol para separatis. Menurut pengamatan 'Abd al-Raziq, nyaris semua khalīfah dari zaman ke zaman dinobatkan dan dipertahankan dengan kekuatan fisik dan ketajaman pedang, dan mungkin dengan beberapa pengecualian, misalnya Abu Bakar, 'Umar dan Utsman.12 'Abd al-Raziq tidak menolak penegakan sistem pemerintahan untuk menjalankan syiar-syiar agama dalam berbagai bentuk dan demi kemaslahatan umum. Hal itu memang sangat diperlukan namun bentuknya tidak harus sistem khiläfah an sich.

Terhadap alasan bahwa wajib atau harus ada yang diangkat menjadi khaliffah demi melindungi kelestarian Islam dan kepentingan rakyat, 'Abd al-Raziq menh. 151.

8`Abd al-Rahman Ibn Khaldun, Muqaddimah Ibn Khaldun, (Beirut: Dar al-Kutub al-'Ilmiyah, 2002),

${ }^{9}$ Di sini perlu dibedakan antara istilah khiläfah dan khalïfah. Bila khiläfah merupakan lembaga/ institusinya, maka khalifah adalah pejabat yang menjalankan tugas kepemimpinan atau memimpin lembaga tersebut. 'Abd al-Rahman Ibn Khaldun, Muqaddimah..., h. 151. 297.

${ }^{10}$ Albert Hourani, Pemikiran Liberal di Dunia Arab, terj. Suparno, dkk., (Bandung: Mizan, 2004), h.

${ }^{11}$ Albert Hourani, Pemikiran Liberal..., h. 297-298.

${ }^{12}$ Munawir Sjadzali, Islam dan Tata Negara..., h. 141. 
jawab bahwa memang benar dalam hidup bermasyarakat tiap kelompok manusia memerlukan penguasa yang mengatur dan melindungi kehidupan mereka, lepas dari agama dan keyakinan mereka, apakah Islam, Nasrani, Yahudi atau penganut agama lain, dan bahkan mereka yang tidak beragama sekalipun. Penguasa itulah pemerintah. Tetapi pemerintah itu tidak harus berbentuk khiläfah, melainkan dapat beraneka ragam bentuk dan sifatnya, apakah konstitusional atau kekuasaan mutlak, apakah republik atau diktator dan sebagainya. Tegasnya, tiap bangsa harus mempunyai pemerintahan, tetapi baik bentuk maupun sifat pemerintahan itu tidak harus satu (khiläfah) dan boleh beraneka ragam..$^{13}$

Kedua, Muhammad seorang Rasul bukan penguasa negara. 'Abd al-Raziq mengamati bila umat Islam umumnya cenderung pada keyakinan bahwa Nabi SAW adalah Rasul sekaligus penguasa politik, beliau adalah penguasa agama dan pemimpin pemerintahan. Masyarakat Muslim cenderung pada anggapan bahwa Islam merupakan persatuan politik dan agama yang asas-asasnya dibangun oleh Rasul SAW, tidak terkecuali Ibn Khaldun pun beranggapan demikian dalam karya Muqaddimah-nya. ${ }^{14}$

'Abd al-Raziq dengan tegas menampik pandangan-pandangan demikian. Ia mengajukan sejumlah pertanyaan interogatif: Jika Rasul telah meletakkan asasasas sistem politik atau mensyariatkan peletakkan asas-asasnya, lalu mengapa pemerintahan beliau sepi dari rukun-rukun dawlah dan pilar-pilar pemerintahan? Mengapa tidak diketahui sistem-sistem tentang peradilan dan perwalian? Mengapa beliau tidak berbicara kepada rakyatnya mengenai sistem kekuasaan dan kaidah-kaidah shūrā? Dan mengapa pula beliau membiarkan para ulama berkubang dalam kebingungan mengenai persoalan sistem pemerintahan pada zamannya?

Menurut 'Abd al-Raziq, jabatan risalah memang menyediakan pelakunya ruang kuasa yang lebih luas ketimbang yang terbentang di antara hakim dan orang yang dihukumi bahkan lebih luas dari pada yang ada di antara bapak dan anak. Rasul mempunyai tugas yang tidak bisa diimbangi. Termasuk dalam lingkaran tugas beliau adalah berhubungan dengan rohani yang berdiam dalam raga, mengangkat hijab untuk membuka hati yang ada dalam dada, menggugah hati para pengikutnya dalam upaya menguak sumber cinta dan benci, baik dan

13Munawir Sjadzali, Islam dan Tata Negara.., h. 141.

14‘Ali ‘Abd al-Raziq, al-Islām..., h. 61. 
buruk, aliran dari pemikiran mereka yang terdalam, ruang godaan yang tersembunyi, sumber tujuan dan landasan dari karakter moral mereka.

Beliau juga memiliki tugas lembut dalam mengelola hubungan antara teman dengan teman, sekutu dengan sekutu, juragan dengan hambanya, orang tua dan anaknya, dan dalam mengelola ikatan yang tidak muncul kecuali di antara suamiistri. Beliau menjaga sesuatu yang zahir dan batin, mengatur urusan-urusan jasmani dan rohani serta hubungan vertikal dan horisontal manusia. Risalah menuntut pelakunya hubungan sejati dengan segenap jiwa, hubungan ri'ayah dan tadbir, serta pengelolaan sejati dengan pengelolaan yang tiada batas. ${ }^{15}$

Sebagai seorang Nabi, Muhammad memiliki kualitas-kualitas yang menjadi tuntutan tugasnya, dan juga kekuasaan. Kekuasaan ini lebih luas dari kekuasaan seorang pemimpin politik dan berbeda dalam sifatnya. Kekuasaan spiritual inilah yang memiliki sumbernya dalam ketundukan hati yang bebas, tulus dan total, tidak berdasarkan, sebagaimana kekuasaan politik, pada ketundukan yang dipaksakan dari badan jasmani. Tujuannya bukan untuk mengatur kepentingankepentingan kehidupan duniawi, melainkan untuk membimbing manusia menuju Tuhan. Atas dasar kekuasaannya ini, Muhammad menciptakan sebuah komunitas, tetapi tidak dalam bentuk yang umumnya kita sebut sebuah negara. Ini adalah sebuah komunitas yang tidak memiliki hubungan esensial dengan sebuah pemerintahan, atau sebuah bangsa dengan bangsa yang lainnya. ${ }^{16}$

Lebih jauh, 'Abd al-Raziq memperkuat dengan dalil-dalil al-Qur'an bahwa Nabi Muhammad SAW tidak memiliki urusan dengan kekuasaan politik. Ayatayat al-Qur'an mendedahkan bahwa pekerjaan Nabi adalah pekerjaan langit yang sama sekali tidak terlampaui oleh seluruh batas-batas kekuasaan. ${ }^{17}$ Mengikuti argumen 'Abd al-Raziq, di sini al-Qur'an dengan tegas melarang Nabi bertindak sebagai pemelihara manusia. Beliau bukan wakil, bukan pemaksa (jabbār), bukan pengawas dan beliau tidak mempunyai hak memaksa manusia agar menjadi Mukmin. Begitu pun jika beralih menuju sunnah Nabi, maka hadits-hadits menunjukkan beliau sebagai pembawa risalah bukan penguasa politik.

Melalui postulat-postulat di atas, 'Abd al-Raziq menyimpulkan bahwa bukan hanya al-Qur'an yang menghalang-halangi kaum Muslim untuk berkeyakinan

\footnotetext{
${ }^{15 ‘ A l i ~ ' A b d a l-R a z i q, ~ a l-I s l a ̄ m . . ., ~ h . ~} 80$.

${ }^{16}$ Albert Hourani, Pemikiran Liberal..., h. 300-301.

${ }^{17}$ Misalnya QS. al-Syu'ara: 48, QS. al-Isra': 54, QS. Qaf: 45.
} 
bahwa Rasul SAW, dengan risalah keagamaannya, menyeru kepada pemerintahan politik. Bukan pula sunnah yang mencegah untuk demikian. Baik al-Qur'an dan Sunnah, maupun hukum akal mengisyaratkan hal serupa. Dengan demikian, tidak ada pemerintahan, dawlah, orientasi-orientasi politik atau tujuan-tujuan para penguasa atau umara di sana. ${ }^{18}$

Ketiga, sistem politik Islam diserahkan pada akal manusia. Dengan menelusuri argumen-argumen 'Abd al-Raziq sejauh ini bahwa sistem khiläfah bukan model pemerintahan dalam Islam dan Rasul SAW hanya berfungsi sebagai penyampai risalah, bukan penguasa negara, lalu bagaimanakah bentuk pemerintahan dalam Islam? Dalam perspektif 'Abd al-Raziq, persoalan politik atau pemerintahan merupakan salah satu tujuan duniawi yang diserahkan oleh Allah kepada akal manusia. Allah mengizinkan manusia mengurusnya sesuai petujuk akal, ilmu pengetahuan, kepentingan, selera, serta orientasi mereka. Kebijaksanaan Allah ini dimaksudkan agar manusia tetap berada dalam keanekaragaman. ${ }^{19}$

Dalam al-Qur'an memang terdapat istilah uli al-amr yang secara umum berarti ketaatan kepada pemimpin, misalnya dalam Surat al-Nisa ayat 59 berikut:

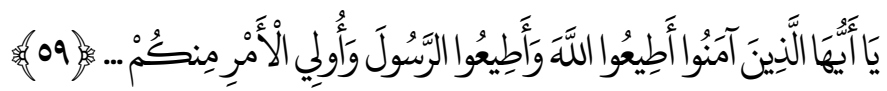

"Wahai orang-orang yang beriman, taatilah Allah dan taatilah Rasul(Nya), dan ulil amri di antara kamu."

Namun istilah uli al-amr dalam ayat tersebut, bagi 'Abd al-Raziq, tidak mengandung dalil yang cocok untuk diterapkan bagi wajibnya kekhilafahan. Kandungan maksimal dari istilah tersebut yakni adanya keharusan bagi kaum Muslim untuk memiliki sekelompok orang yang dapat dijadika rujukan bagi persoalan-persoalan yang mereka hadapi. Itulah makna yang lebih luas, lebih kaya, dan lebih umum daripada hanya arti khiläfah. ${ }^{20}$

Dalam konteks ini, cukup menarik untuk melihat perspektif Quraish Shihab tentang beragam makna uli al-amr dalam tafsirnya, al-Mishbah. Dalam pandangan Quraish, dari segi bahasa uli adalah bentuk jamak dari wāliy yang berarti pemilik atau yang mengurus atau dan menguasai. Bentuk jamak dari kata tersebut menunjukkan bahwa mereka itu banyak, sedang kata al-amr adalah

18`Ali ‘Abd al-Raziq, al-Islām..., h. 93-94.

${ }^{19} \mathrm{QS}$. Hud [11]: 118.

20`Ali ‘Abd al-Raziq, al-Islām..., h. 23. 
perintah atau urusan. Dengan demikian uli al-amr adalah orang yang berwenang mengurus urusan kaum Muslim. Mereka adalah orang yang diandalkan dalam menangani persoalan-persoalan kemasyarakatan. Dari sini, istilah uli al-amr bisa ditarik beberapa makna: a) Mereka adalah para penguasa (pemerintah); b) Mereka adalah ulama; dan c) Mereka adalah orang-orang yang mewakili masyarakat dalam berbagai kelompok dan profesinya baik yang bersifat legal formal (seperti polisi) maupun yang bersifat non formal (seperti ilmuwan/ cendekiawan). ${ }^{21}$ Dengan demikian, memang kurang tepat bila hanya membatasi arti uli al-amr sebatas seorang khaliffah atau sistem khiläfah semata.

Sampai pada titik ini, 'Abd al-Raziq tidak menawarkan sebuah sistem pemerintahan atau bentuk kekuasaan politik apa pun, entah sistem monarki, aristokrasi, oligarki, teokrasi, atau pun demokrasi. Semuanya diserahkan kepada rasio manusia dan sesuai setting sosial masyarakat masing-masing, sebab setiap komunitas, ruang, dan waktu mempunyai keunikan tersendiri yang tidak dimiliki lainnya sehingga solusinya harus unik pula.

Pandangan-pandangan 'Abd al-Raziq di atas, tidak ayal lagi sangat kontroversial. Ia mewakili tipe pemikiran yang langka atau arus minoritas dari kebanyakan pemikir sezamannya. Karena itu wacana yang ia gulirkan tentang sistem pemerintahan dalam Islam tersebut mengundang kritik tajam dari para pemikir Muslim. Sebut saja misalnya Rasyid Ridha, Muhammad Bakhit, ${ }^{22}$ Muhammad Imara, Dhiya al-Din ${ }^{23}$ dengan kritiknya yang sangat luas, serta bahkan Mohammad Arkoun melontarkan kritik terhadap 'Abd al-Raziq.

Begitu pula Arkoun menolak secara tegas jika dikatakan bahwa Muhammad tidak memiliki fungsi politik, tapi hanya agama. Arkoun senada dengan Imara yang menyatakan bahwa 'Abd al-Raziq tidak mampu memahami nilai politis dalam prestasi Nabi. ${ }^{24}$ Arkoun menginginkan negara demokrasi yang prinsipprinsipnya bisa digali dari agama Islam dan diperkaya dengan yang lain (eklektik). ${ }^{25}$ Bila ditilik melalui perspektif umum orang-orang Barat, menurut

\footnotetext{
${ }^{21}$ Quraish Shihab, Tafsir al-Mishbah, Vol. 2, (Jakarta: Lentera Hati, 2000), h. 460-461.

${ }^{22}$ Albert Hourani, Pemikiran Liberal..., h. 304.

${ }^{23}$ Dhiya al-Din al-Rais, Islam \& Khilafah, terj. Afif Mohammad, (Bandung: Pustaka, 1985).

${ }^{24}$ Tentang fungsi politis Nabi ini secara agak luas dibahas oleh Fethullah Gulen, Versi Terdalam Kehidupan Rasul Allah Muhammad SAW, terj. Tri Wibowo Budi Santoso, (Jakarta: Grafindo Persada, 2002), h. 233-272.

${ }^{25}$ Mengenai kritik Arkoun secara lebih luas ada dalam Leonard Binder, Islam Liberal, terj. Imam Muttaqin, (Yogyakarta: Pustaka Pelajar, 2001), h. 231-247.
} 
Karen Armstrong, kebanyakan mereka justru bingung dalam memahami keterlibatan Muhammad dalam berbagai kegiatan politik. Bagaimana mungkin seorang tokoh kesucian ruhaniah ikut serta dalam kegiatan yang berkaitan dengan kekuasaan diniawi?26

Namun Armstrong berargumentasi secara komparatif bahwa Muhammad memang sangat berbeda dengan Santo Paulus atau Yesus. Jika Yesus hanya menjadi manusia suci dan bernuansa ilahiah, tidak demikian halnya dengan Muhammad. Muhammad bukan cuma memiliki bakat spiritual tapi juga talenta politik. Bila Yesus hanya bergelut dengan perintah-perintah keagamaan, Muhammad terjun pula dalam gelanggang perpolitikan duniawi di mana ia bisa sangat marah dan keras, namun ia juga bisa lembut, menghargai, rapuh dan luar biasa baik. ${ }^{27}$ Bahkan dengan gamblang Armstrong menyatakan kalau Muhammad sedang mengupayakan sebuah solusi politik yang sama sekali baru bagi umatnya pada abad ke-7 Masehi. ${ }^{28}$

Tentu saja, yang dibaca oleh Armstrong dan pengamat lain dari Barat bukan konsep politik Islam yang rigid, yakni mendirikan negara Islam. Akan tetapi bagaimana mengimplementasikan nilai-nilai prinsip dalam Islam ke dalam tataran pemerintahan yang bukan hanya berguna bagi umat Islam an sich melainkan juga bagi komunitas lain non-Muslim, sebagaimana dicontohkan Muhammad di masa silam. Dengan kata lain, menyosialisasikan nilai-nilai Islam yang berwajah inklusif dan pluralis sehingga bisa mengayomi semua lapiasan sosial yang berbeda.

Terlepas dari berbagai kritik yang dilontarkan para pemikir terhadap 'Abd alRaziq, gagasan 'Abd al-Raziq tetap mempunyai signifikansi tersendiri. Setidaknya konsep-konsepnya itu merupakan hasil ijtihad terhadap Islam tentang kebebasan akal yang sampai hari ini masih diapresiasi oleh para pemikir kontemporer dalam memperkaya wacana perpolitikan dalam Islam. Terlebih lagi saat sekarang begitu maraknya gerakan-gerakan fundamental yang ingin merekonstruksi sistem pemeritahan Islam klasik secara literal dan ternyata mayoritas negara Muslim hingga hari ini masih gagal membentuk sistem politik yang demokratis. ${ }^{29}$ Maka tawaran liberal dari 'Abd al-Raziq mungkin bisa menjadi

\footnotetext{
26Jalaluddin Rakhmat, Reformasi Sufistik, (Bandung: Pustaka Hidayah, 1998), h. 17-18.

${ }^{27}$ Karen Armstrong, Muhammad, (San Fracisco: Harper Collins, 1993), h. 51-52, 261-264.

${ }^{28}$ Karen Armstrong, History of God, (New York: Ballantine Books, 1993), h. 140.

${ }^{29}$ Mun'im A. Sirry, Dilema Islam Dilema Demokrasi, (Bekasi: Gugus Press, 2002), h. 10-11, 33-34.
} 
cermin bahwa bukan hanya norma-norma agama semata yang harus berperan melainkan juga kebebasan nalar manusia mesti diberi ruang untuk berbicara secaraluas.

\section{Paradigma Formalistik (Integralistik)}

Paradigma formalistik memandang agama Islam sebagai suatu agama yang sempurna dan sangat lengkap, yang meliputi tidak saja tuntunan moral dan peribadatan, tetapi juga petunjuk-petunjuk mengenai cara mengatur segala aspek kehidupan politik, ekonomi, dan sosial. Oleh karenanya untuk pemulihan kejayaan dan kemakmuran, umat Islam harus kembali kepada agamanya yang sempurna dan komprehensif, kembali kepada kitab sucinya, al-Qur'an dan Sunnah Nabi SAW, mencontoh pola hidup Rasul SAW dan umat Islam generasi pertama, serta tidak perlu atau bahkan jangan meniru pola atau sistem politik, ekonomi, dan sosial Barat. ${ }^{30}$

Aspek politik yang hendak menjadikan Islam sebagai pondasi pemerintahan dalam segala dimensinya inilah yang ditampilkan oleh gerakan Ikhwanul Muslimin di Mesir dan mempunyai pengaruh yang cukup luas bagi umat Islam diberbagai belahan negara. Deklarasi tentang perlunya kembali kepada ajaran fundamental Islam dengan target khiläfah islämiyyah atau mendirikan negara Islam dengan patron Nabi SAW dan sahabat empat mulai dirintis oleh Hassan alBanna, Sayid Quthb, Said Hawwa, dan lainnya.

Hassan al-Banna, yang merupakan pendiri gerakan Ikhwanul Muslimin, menjelaskan salah satu misi gerakannya adalah untuk mendirikan negara Islam, yang ditegakkan di atas ajaran Islam, menerapakan aturan-aturan sosial, mengadvokasi prinsip-prinsip yang benar dan menyebarkan dakwahnya kepada seluruh umat manusia. Al-Banna memperingatkan kaum Muslim secara keseluruhan bahwa sepanjang negara seperti itu belum ada, setiap Muslim berdosa dan mereka bertanggungjawab di hadapan Allah karena kegagalan dan kelalaian mereka untuk mendirikannya. Al-Banna juga menganggap partai-partai politik sebagai ancaman potensial terhadap persatuan Islam yang baginya umat diperlukan untuk membangun kembali khilāfah. ${ }^{31}$

\footnotetext{
30Munawir Sjadzali, Islam dan Tata Negara..., h. 148.

${ }^{31}$ Mun'im A. Sirry (ed.), Islam Liberalisme Demokrasi..., h. 149-151.
} 
Secara sederhana, dapat dikatakan bahwa gerakan Ikhwanul Muslimin merupakan gerakan politik yakni gerakan yang menuntut perbaikan dari dalam terhadap pemerintah, meluruskan persepsi yang terkait dengan hubungan umat Islam terhadap bangsa-bangsa lain di luar negeri, mendidik bangsa agar memiliki kemuliaan dan menjaga identitasnya. Ungkapan tersebut menjelaskan pula bahwa aspek politik berkaitan dengan apa yang berhubungan dengan pemerintahan tata negara dan hubungan antara pemerintah dan rakyat. Demikian juga hubungan antara negara, dengan penjajah, dan permasalahan yang terkait. Dengan kata lain, politik adalah upaya memikirkan persoalan internal dan eksternal umat Islam.

Dimensi internal politik mengurus persoalan pemerintahan, menjelaskan fungsi-fungsinya, merinci kewajiban dan hak-haknya, melakukan pengawasan terhadap para penguasa untuk kemudian dipatuhi jika mereka melakukan kebaikan dan dikritik jika melakukan kesalahan. Sedangkan dimensi eksternal, memelihara kemerdekaan dan kebebasan bangsa, mengantarkannya mencapai tujuan yang akan menempatkan kedudukannya di tengah-tengah bangsa lain, serta membebaskannya dari penindasan dan intervensi pihak lain dalam urusanurusannya.

Paradigma formalistik menemukan momentumnya pada sosok Sayyid Quthb, yang dikenal sebagai ideolog paling militan Ikhwanul Muslimin. Quthb membagi masyarakat dalam dua kategori: masyarakat yang betul-betul beriman dan masyarakat jahiliah. Realitas kehidupan modernitas dalam pandangan Quthb merupakan fenomena kejahiliyahan. Simak penjelasannya mengenai fenomena kejahiliahan yang telah merata dalam panggung kehidupan masyarakat modern:

"Kita sekarang tenggelam dalam kejahiliahan, kejahiliahan seperti kejahiliahan semasa awal Islam, hanya saja mungkin lebih dalam dan lebih gelap. Segala sesuatu di sekitar kita mencerminkan kejahiliahan: ide-ide orang, kepercayaan, tradisi, kebudayaan, kesenian, aturan, dan hukum mereka. Bahkan semua yang kita anggap sebagai kebudayaan Islam, sumber Islam, pemikiran dan filsafat Islam, semuanya adalah konstruksi kejahiliahan. Inilah mengapa nilai-nilai Islam tidak menghunjam dalam jiwa kita, mengapa pandangan kesemestaan Islam tetap gelap dalam pikiran kita, mengapa tidak ada generasi yang muncul di antara kita yang bisa menandingi generasi awal Islam."32

${ }^{32}$ Roxanne L Euben, Musuh dalam Cermin, terj. Satrio Wahono, (Jakarta: Serambi, 2002), h. 114-115. 
Melalui diognosa tersebut, dalam penglihatan Quthb, semua Muslim wajib berhijrah ke tanah Islam sejati dan mereka yang tidak melakukannya dipandang berstatus murtad dan kafir. Quthb menegaskan bahwa kedaulatan semata-mata ada di tangan Tuhan, sehingga dalam masyarakat Islam tulen, Tuhanlah satu-satunya pembuat hukum, dan keadilan sempurna dapat dicapai jika penguasa sungguh-sungguh mengimplementasikan hukum Tuhan. ${ }^{33}$

Masyarakat jahiliyah sejatinya merupakan masyarakat yang menolak untuk tunduk kepada kedaulatan Tuhan dalam ranah keimanan, ibadah, dan hukum, lewat penolakan terhadap eksistensi-Nya, lewat pembatasan otoritas-Nya, atau penggantian kedaulatan-Nya dengan tuhan-tuhan palsu. Intinya adalah penolakan terhadap kedaulatan ilahiah dan lebih memilih filsafat dan epistemologi yang mengklaim bahwa manusia memiliki hak untuk menciptakan nilai dan aturan bagi perilaku kolektif. ${ }^{34}$

Dengan tegas Quthb mendefinisikan masyarakat jahiliah secara dikotomik antara Islam hakiki (menurut pemahamannya) dan semua masyarakat lain nonMuslim:

"Namun apakah masyarakat jahili itu? Masyarakat jahiliah adalah segala masyarakat yang bukan masyaarakat Islam. Jika kita menginginkan definisi khusus, maka kita bisa mengatakan, sebuah masyarakat itu jahili jika masyarakat itu tidak mengabdi semata-mata kepada Allah dan tidak menjabarkan pengabdian kepada Allah ini dalam kepercayaan dan pandangan kesemestaannya, dalam ritual ibadah dan hukumnya. Dengan definisi khusus ini, semua masyarakat mapan di muka bumi sekarang ini sebenarnya terimbas oleh kerangka jāhilīini. ${ }^{35}$

Dalam pengamatan para ahli, penafsiran militan Quthb tentang Islam dalam berbagai aspeknya, tumbuh akibat konfrontasi antara negara Mesir yang represif dan Ikhwanul Muslimin pada tahun 1950-an dan 1960-an. Selama tahun 1950an, Quthb menjadi sosok paling berpengaruh di antara anggota yang lebih muda dan lebih militan di Ikhwanul Muslimin. Penahanan selama sepuluh tahun lebih dan penyiksaan yang dialaminya merupakan katalis utama dalam mengubahnya dari seorang intelektual dan penulis religius arus utama terkemuka menjadi

\footnotetext{
${ }^{33}$ Khaled Abou Fadl, Selamatkan Islam Muslim Puritan, terj. Helmi Mustofa, (Jakarta: Serambi, 2005), h. 102.

${ }^{34}$ Quthb memandang Islam juga sebagai sebuah system yang mencakup segala dimensi kehidupan manusia. Lihat: Sayid Quthb, Karakteristik Konsepsi Islam, terj. Muzakkir, (Bandung: Pustaka, 1990).

${ }^{35}$ Roxanne L. Euben, Musuh dalam Cermin, h. 116.
} 
seorang radikal militan yang mengutuk Pemerintah Mesir maupun Amerika dan memberi legitimasi jihad secara militan. ${ }^{36}$

Berpijak pada keyakinan yang demikian, Quthb menyerukan didirikannya sebuah pemerintahan Islam yang berada di bawah satu pemerintahan supra nasional, dengan sistem sentralisasi kekuasaan, dan tidak mengenal batas-batas kebangsaan. Dalam negara Islam memang dijamin kebebasan dan persamaan hak bagi golongan-golongan non-Muslim. Tetapi hak untuk menjadi kepala negara dan hak untuk ikut memilih kepala negara merupakan hak-hak eksklusif orang-orang Islam saja. ${ }^{37}$

Selanjutnya, dalam paradigma Said Hawwa, implementasi sistem politik Ikhwanul Muslimin setidaknya secara garis besar mencakup tiga aspek. ${ }^{38} \mathrm{Per}$ tama, mencetak kepribadian manusia dengan corak islami secara käffah. Pembentukan pribadi islami di sini meliputi lima akhlak asasi yaitu cinta Allah, kasih sayang terhadap orang-orang mukmin, bersikap keras terhadap orangorang kafir, jihad, dan melepaskan loyalitas dari orang-orang kafir.

Kedua, mendirikan negara Islam di setiap negara. Bagi Hawwa, aspek ini merupakan kewajiban yang telah dilupakan oleh kebanyakan generasi Muslim di negara-negara Islam. Baginya, pendirian negara Islam bukan perkara yang perlu diperdebatkan lagi. Kewajiban setiap Muslim adalah berusaha untuk menegakkan negara Islam di negaranya masing-masing.

Sebagian pemikir Ikhwanul Muslimin, seperti Halim Mahmud, secara tegas memang menolak segala sistem pemerintahan produk Barat, bahkan sistem demokrasi. Menurutnya, sistem demokrasi Barat yang diaplikasikan oleh sebagian besar masyarakat Barat dan juga sebagian Eropa dewasa ini dianggap tidak akan pernah bisa mewakili sistem yang ditawarkan Islam dengan sistem khilāfah-nya. Sistem khilāfah merupakan sistem ideal yang tak tergantikan oleh semua sistem, sekali pun sistem demokrasi. ${ }^{39}$

Ketiga, menyatukan umat Islam dan menghidupkan kembali sistem khilăfah. Bagi kalangan pemikir Ikhwanul Muslimin, satu-satunya bentuk pemerintahan Islam yang sesuai dengan ketentuan syariat Islam adalah sistem khiläfah. Sistem

\footnotetext{
112.

36John L. Esposito, Masa Depan Islam, terj. Eva Y. Nukman \& Edi Wahyu, (Bandung: Mizan, 2010), h.

${ }^{37}$ Munawir Sjadzali, Islam dan Tata Negara.., h. 152.

${ }^{38}$ Said Hawwa, Jundullah, terj. Hamim Thohari, dkk, (Solo: Era Intermedia, 2002), h. 47-53.

${ }^{39} \mathrm{Halim}$ Mahmud, Wasāil al-Tarbiyah inda Ikhwān al-Musliminn, (Kairo: Dar al-Wafa' li al-Tiba'ah wa al-Tauzi, 1993), h. 44-45, 48.
} 
khiläfah ini dapat diupayakan dengan langkah-langkah sebagai berikut: a) harus ada kerjasama penuh antar berbagai bangsa Muslim dalam masalah budaya, sosial, dan ekonomi; b) membentuk berbagai kesepakatan, membuat lembagalembaga kerjasama dan mengadakan berbagai seminar antar negara; c) membentuk perserikatan bangsa-bangsa Muslim untuk kemudian mengangkat seorang imam yang menjadi penengah, pemersatu, penenteram hati, dan cerminan dari lindungan Allah di muka bumi. ${ }^{40}$

Demikian pula, implementasi politik Islam dalam gerakan Ikhwanul Muslimin didasarkan pada sejumlah tujuan berikut: Pertama, memperkuat kesadaran dan perasaan wajib membebaskan negeri Islam dari setiap kekuasaan asing dan mengusir penjajah dari negeri-negeri Islam dengan cara yang sah. Kedua, membangkitkan kesadaran dan perasaan atas wajibnya mendirikan negara Islam. Ketiga, membangkitkan kesadaran dan perasaan akan wajibnya terwujudnya persatuan Islam. ${ }^{41}$

Dalam paradigma gerakan Ikhwanul Muslimin, yang menjadi kebutuhan vital bagi nasionalisme dan kemanusiaan umat Islam adalah bangkit dari ketertindasan dengan mengembalikan semangat politik Islam sebagaimana yang diajarkan Rasul SAW dan al-khulafä' al-rāshidīn. Dengan kata lain, pengejawantahan sistem pemerintahan Islam atau negara Islam dalam paradigma Ikhwanul Muslimin tersebut akhirnya harus menumbuhkan kesadaran dan kepedulian umat Islam untuk mewujudkan kembali cita-cita politik Islam sebagaimana yang dibangun oleh Rasul SAW dan al-khulafä' al-rāshidīn.42

Dengan perspektif demikian, mereka berupaya membangun kembali sistem khilāfah yang dianggapnya jauh lebih demokratis daripada sistem demokrasi yang ditawarkan oleh peradaban Barat dewasa ini. Akan tetapi, sebagaimana dinyatakan oleh sebagian ahli telaah historis-sosiologis, bahwa kebanyakan manusia kontemporer tidak bisa menjadi religius dalam cara yang sama seperti para pendahulunya di zaman klasik. Sehingga setiap upaya untuk menghadirkan kembali wajah kehidupan agamis era klasik sebagamana adanya secara literalskripturalistik, tentu saja akan mengalami problem yang sangat serius. ${ }^{43}$

\footnotetext{
${ }^{40}$ Halim Mahmud, Wasāill al-Tarbiyah..., h. 121.

${ }^{41}$ Hasan al-Banna, Majmū'at al-Rasāill, (Beirut: Mu’assat al-Risalah, tth.), h. 76-77.

${ }^{42}$ Hasan al-Banna, Majmū'at al-Rasāïli, h. 454. 577.

${ }^{43}$ Karen Armstrong, Berperang Demi Tuhan, terj. Satrio Wahono, dkk, (Bandung: Mizan, 2002), h.
} 
Meminjam bahasa Karl R. Popper dalam The Open Society and Its Enemies, sudut pandang inilah yang barangkali dinamakan sebagai romantisisme yang lebih mengutamakan dambaan emosional ketimbang argumentasi rasional. Dalam bahasa Popper, "Romanticism may seek its heavenly city in the past or in the future; it may preach 'back to nature' or 'forward to a world love and beauty'; but its appeal is always to our emotions rather than to reason", Romantisisme mungkin mencari kota surgawinya di masa lalu atau di masa depan; romantisisme ini bisa mengkhotbahkan 'kembali ke kodrat' atau 'menuju dunia yang penuh cinta dan keindahan'; namun seruannya selalu lebih diarahkan pada emosi kita daripada kepada akal. ${ }^{44}$

Begitu pula ketika Quthb melakukan diskriminasi terhadap non-Muslim bahwa hak untuk memilih dan menjadi kepala negara hanya hak eksklusif orangorang Islam. Tanpa mempersoalkan tentang dapat atau tidak dapat diterimanya ketentuan tersebut, yang jelas bagi negara yang bermasyarakat majemuk, di mana terdapat cukup besar pemeluk-pemeluk agama lain di samping Islam, seperti Mesir dan Indonesia, pelaksanaan ketentuan itu akan berakibat berat dan luas. Apalagi kalau golongan non-Muslim itu juga sama-sama penduduk asli yang berakar sama dalamnya dengan golongan Islam, tentu berat bagi hati nurani untuk membenarkannya. 45

Pandangan formalistik terhadap Islam sebagaimana diungkapkan di atas mempunyai beberapa implikasi. Salah satu di antaranya, pandangan itu telah mendorong lahirnya sebuah kecenderungan untuk memahami Islam dalam pengertiannya yang literal, yang hanya menekankan dimensi luar (exterior)nya. Kecenderungan ini telah dikembangkan sedemikian jauh sehingga terabaikannya dimensi kontekstual dan dalam (interior) dari prinsip-prinsip Islam. ${ }^{46}$

Karena itu, apa yang tersirat di balik penampilan-penampilan tekstualnya hampir-hampir terabaikan, jika bukan terlupakan maknanya. Dalam contohnya yang ekstrem, kecenderungan seperti ini telah menghalangi sementara kaum Muslim untuk dapat secara jernih memahami pesan-pesan al-Qur'an sebagai instrumen Ilahiah yang memberikan panduan nilai-nilai moral dan etis yang benar bagi kehidupan manusia.

${ }^{44}$ Karl L. Popper, Open Society and Its Enemies, (New York-London: Verso, 1981), h. 219.

${ }^{45}$ Munawir Sjadzali, Islam dan Tata Negara..., h. 155-156.

${ }^{46}$ Bahtiar Effendy, Islam \& Negara..., h. 8-9. 
Dalam paradigma formalistik terhadap Islam ini, Qomaruddin Khan menyatakan kritiknya bahwa umumnya mereka meyakini sifat holistik Islam berdasarkan ayat, "Dan telah Kami turunkan kepadamu Kitab Suci untuk menjelaskan segala sesuatu."47 Namun harus diakui makna ayat tersebut cukup problematik jika diartikan bahwa Islam mengandung segalanya dalam setiap detil aspek kehidupan. Dalam perspektif Qomaruddin Khan, hal ini adalah pandangan yang keliru. Ayat itu bermaksud menerangkan bahwa al-Qur'an mengandung penjelasan mengenai setiap aspek panduan moral dan bukan penjelasan tentang segala objek kehidupan. Al-Qur'an bukanlah suatu inventarisasi pengetahuan umum. ${ }^{48}$

\section{Paradigma Substansialistik (Simbiotik)}

Dalam paradigma substansialistik, agama Islam mempunyai seperangkat prinsip dan nilai-nilai tentang kehidupan bermasyarakat, termasuk sistem pemerintahan. Dalam perspektif Muhammad 'Abduh, hakikat pemerintahan Islam tidak bersifat keagamaan tetapi betul-betul bersifat keduniawian. 'Abduh menyatakan bahwa kekuasaan politik harus didasarkan pada kedaulatan rakyat atau kehendak publik. Kedaulatan rakyat ini, menurut 'Abduh harus dibangun atas dasar prisnip-prinsip kebebasan (hurriyah), demokrasi (shūrā), dan konstitusi (qanūn) yang berfungsi sebagai landasan sistem politik dan kekuasaan tersebut.

Konsepsi 'Abduh tentang kebebasan meliputi kebebasan sosial dan politik, termasuk di dalamnya kebebasan berpendapat, kebebasan berbicara, kebebasan memilih, bahkan kebebasan bagi kaum perempuan dalam memperoleh hak-hak mereka. Jika nilai-nilai ini dapat diterapkan dalam kehidupan politik, maka hubungan antara yang berkuasa dan yang dikuasai akan berlangsung dalam interaksi positif dan konstruktif. ${ }^{49}$

Menurut 'Abduh, Islam tidak mengenal adanya kekuasaan agama dalam arti: a) Islam tidak memberikan kekuasaan kepada seseorang atau sekelompok orang untuk menindak orang lain atas nama agama atau berdasarkan mandat dari agama; b) Islam tidak membenarkan campur tangan seseorang, penguasa

\footnotetext{
${ }^{47}$ QS. al-Nahl [16]: 89.

${ }^{48}$ Qomaruddin Khan, Tentang Teori Politik Islam, terj. Taufik Adnan Amal, (Bandung: Pustaka, 1987), h. 92. Bandingkan dengan Quraish Shihab, Membumikan al-Qur'an, (Bandung: Mizan, 1997), h. 52.

${ }^{49}$ Pramono U. Tanthowi (ed.), Begawan Muhammadiyah, (Jakarta: PSAP, 2005), h. 104.
} 
sekalipun, dalam kehidupan dan urusan keagamaan orang lain; dan c) Islam tidak mengakui hak seseorang untuk memaksakan pengertian, pendapat, dan penafsirannya tentang agama atas orang lain..$^{50}$

Tentu saja 'Abduh mengakui bahwa Islam itu bukan agama semata-mata, melainkan mempunyai hukum-hukum yang mengatur hubungan antar sesama Muslim dan sesama makhluk hidup, yang untuk pelaksanaan dan pengawasan berlakunya memerlukan adanya penguasa lengkap dengan aparat-aparatnya. Menurutnya tugas itu merupakan tanggungjawab kepala negara beserta perangkat pemerintahnya. Tetapi kepala negara sebagai penguasa sipil diangkat oleh rakyat dan bertanggungjawab kepada rakyat. Rakyat adalah pemilik kekuasaan yang sesungguhnya dan yang berhak menurunkan kepala negara dari tahta kekuasaannya. Kepala negara bukanlah sebagai wakil atau bayangan Allah di muka bumi, yang mewajibkan tiap Muslim taat kepadanya demi agama meskipun perilaku atau kebijkasanaannya bertolak belakang dengan ajaran agama. ${ }^{51}$

Menurut sebagian pengamat, melalui beberapa pokok pikirannya tersebut, 'Abduh memang sedang berupaya untuk merekonsiliasi antara gagasan Islam dan Barat. 'Abduh misalnya mengusulkan bahwa maṣlahah (interest) dalam pemikiran Islam sesuai dengan manfaat (utility) dalam pemikiran Barat. Demikian juga ia mempersamakan shūrā dengan demokrasi, dan ijmā' dengan konsensus. ${ }^{22}$ 'Abduh yakin bahwa hubungan Islam dengan dunia modern sebagai persoalan krusial yang harus dihadapi oleh masyarakat Muslim. ${ }^{53}$

Jadi di sini, meskipun 'Abduh meyakini doktrin Islam mencakup prinsipprinsip tentang kehidupan sosial dan politik, namun ia menolak jika sistem pemerintahan itu harus berbentuk negara Islam atau khiläfah islāmiyyah, dengan kembali kepada tipe era klasik. Bagi 'Abduh, persoalan bentuk pemerintahan dalam Islam sepenuhnya diserahkan pada penalaran umat Islam, walaupun harus tetap mengaplikasikan prinsip-prinsip kebebasan, keadilan, kerukunan, kedamaian, dan egalitarianisme misalnya.

Selanjutnya, Muhammad Husain Haikal mengamini pandangan 'Abduh tentang hubungan agama Islam dan negara. Dalam perspektif Haikal, prinsip-

50 Munawir Sjadzali, Islam dan Tata Negara..., h. 131.

51Munawir Sjadzali, Islam dan Tata Negara..., h. 132.

52Lihat: Komaruddin Hidayat, Wahyu di Langit.., h. 55, 103.

53Mun'im A. Sirry (ed.), Islam Liberalisme..., h. 142. 
prinsip dasar kehidupan kemasyarakatan yang diberikan oleh al-Qur'an dan sunnah tidak ada yang langsung berkaitan dengan ketatanegaraan. Islam tidak memberikan petunjuk yang langsung dan rinci tentang bagaimana umat Islam mengatur urusan negara. Dalam kehidupan sosial dan politik, Islam hanya meniupkan spirit keimanan pada Tuhan Yang Maha Esa, yang diikuti prinsipprinsip dasar yang berupa persamaan, persaudaraan, dan kebebasan.

Menurut Haikal, Islam hanya meletakkan prinsip-prinsip dasar bagi peradaban manusia, dan ketentuan-ketentuan dasar yang mengatur perilaku manusia dalam kehidupan dan pergaulan dengan sesamanya, yang pada gilirannya akan mewarnai pola kehidupan politik. Adapun prinsip-prinsip yang diletakkan oleh Islam bagi peradaban manusia menurut Haikal adalah: iman akan keesaan Tuhan, percaya tentang adanya hukum alam atau Sunnah Allah yang pasti dan tidak pernah berubah, dan yang terakhir persamaan..$^{54}$

Prinsip tauhid atau keesaan Tuhan merupakan prinsip pokok yang diserukan oleh agama Islam sebagai asas tunggal bagi kehidupan bersama. Prinsip dasar kedua yang diletakkan oleh Islam bagi peradaban manusia adalah kepercayaan bahwa alam semesta, termasuk kehidupan manusia, tunduk kepada Sunnah Allah atau hukum alam, dan Sunnah Allah tersebut tidak pernah berubah dan tidak akan berubah. Sebagai kelanjutan prinsip tauhid dan Sunnah Allah yang tidak berubah, prinsip persamaan menekankan bahwa semua manusia sama kedudukannya di hadapan Tuhan, sama hak dan kewajibannya. ${ }^{55}$

Singkatnya menurut Haikal, di dalam Islam tidak terdapat satu sistem pemerintahan yang baku. Umat Islam bebas menganut sistem pemerintahan yang bagaimana pun asalkan sistem tersebut menjamin persamaaan antara para warga negaranya, baik hak maupun kewajiban, dan juga di depan hukum dan pengolalan urusan negara diselenggarakan atas shūrā atau musyawarah, dengan berpegang kepada tata nilai moral dan etika yang diajarkan Islam bagi peradaban manusia. Dengan perkataan lain, sistem pemerintahan yang sesuai dengan ketentuan-ketentuan Islam adalah sistem yang menjamin kebebasan dan berasaskan prinsip bahwa pengangkatan kepala negara dan kebijaksanaannya hsrus sepersetujuan rakyat, bahwa rakyat berhak mengawasi pelaksanaan pemerintahan dan meminta pertanggungjawaban. Islam mengimbau kepada

${ }^{54}$ Munawir Sjadzali, Islam dan Tata Negara..., h. 183-187.

55Munawir Sjadzali, Islam dan Tata Negara..., h. 183-187. 
umat manusia, khususnya umat Islam, agar berusaha melaksanakan prinsipprinsip tersebut sejauh kemampuan. ${ }^{56}$

Paradigma substansialistik tidak memformat sistem negara Islam atau dawlah islāmiyyah, sebab mereka juga mengamati bahwa istilah tersebut secara eksplisit tidak ada di dalam al-Qur'an maupun Sunnah. Dalam al-Qur'an, yang mendekati kata daulah adalah dalam Surat al-Hasyr ayat 7 yang meyebutkan bahwa agar kekayaan jangan hanya beredar di kalangan orang-orang kaya saja (kay lā yakūna dūlatan bayna '-aghniyā'i minkum). Kemudian dalam Surat AliImran ayat 140 yang mengatakan "... masa kejayaan dan kehancuran itu Kami pergilirkan di antara manusia .... (... wa tilka ayyāmu nudāwiluhā bayna 'n-nās...).57

Dari sudut pandang ini, bagi mereka al-Qur'an memang bukanlah buku tentang ilmu politik. Kendati demikian, penting untuk dicatat bahwa pendapat seperti ini juga tetap mengakui bahwa al-Qur'an mengandung nilai-nilai dan ajaran-ajaran yang bersifat etis mengenai aktivitas sosial dan politik umat manusia. Sebagaimana telah diungkapkan oleh 'Abduh dan Haikal, ajaran-ajaran ini mencakup prinsip-prinsip tentang keadilan, kesamaan, persaudaraan, dan kebebasan. Berdasarkan pandangan tersebut, sepanjang negara berpegang kepada prinsip-prinsip seperti itu, maka mekanisme yang diterapkannya adalah sesuai dengan ajaran-ajaran Islam..$^{58}$

Dengan alur argumentasi semacam ini, pembentukan sebuah negara Islam dalam pengertiannya yang formal dan ideologis tidaklah begitu penting. Bagi mereka, yang terpenting adalah bahwa negara - karena posisinya yang bisa menjadi instrumental dalam merealisasikan ajaran-ajaran agama- menjamin tumbuhnya nilai-nilai dasar seperti itu. Jika demikian halnya, maka tidak ada alasan teologis atau religius untuk menolak gagasan-gagasan politik mengenai kedaulatan rakyat, negara-bangsa sebagai unit teritorial yang sah, dan prinsipprinsip umum teori politik modern lainnya. Dengan kata lain, sesungguhnya tidak ada alasan yang kuat untuk meletakan Islam dalam posisi yang betentangan dengan sistem politik modern. ${ }^{59}$

\footnotetext{
56Munawir Sjadzali, Islam dan Tata Negara..., h. 188-189.

57Laksmi Pamuntjak, dkk, Tidak Ada Negara Islam, (Jakarta: Djambatan, 2004), h. 135-136.

58Baca: Fazlur Rahman, "Islam and Political Action: Politics in the Service of Religion", dalam Nige Biggar, et.al (ed.), Cities of Gods: Faith, Politics and Pluralism in Judaism, Christianity and Islam, (New York: Greenwood Press, 1986), h. 154.

${ }^{59}$ Bahtiar Effendy, Islam \& Negara..., h. 14.
} 
Dalam konteks klasik, prinsip-prinsip keterbukaan, kebebasan menyatakan aspirasi, partisipasi aktif masyarakat luas secara demokratis, dan musyawarah sebenarnya telah dicontohkan dengan sangat indah dalam kepemimipinan Rasul SAW. Beberapa eksemplar demonstratif berikut ini kiranya memang perlu ditayangkan di sini. Menjelang perang Badar Nabi Muhammad memutuskan posisi bagi pasukan Islam pada suatu tempat dekat suatu mata air. Kemudian salah seorang dari kelompok Anshar, bernama Hubab ibn Mundhir datang menghadap Muhammad dan menanyakan apakah keputusan Nabi Muhammad itu atas petunjuk Allah atau keputusan itu diambil berdasarkan perhitungan sebagai strategi untuk memenangakan peperangan. Nabi menjawab bahwa keputusan itu semata-mata sebagai pemikirannya sendiri dalam rangka mengatur strategi perang dan bukan berdasarkan wahyu. Karena itu Hubab memberikan pikirannya bahwa tempat yang telah dipilih Nabi kurang tepat dan mengusulkan "agar kita maju lebih ke muka ke mata air yang lebih depan. Kita bawa banyak tempat air untuk kita isi dengan mata air itu, kemudian kita tutup dengan pasir kalau nanti misalnya terpaksa mundur kita masih dapat minum sedangkan musuh akan kehausan". Nabi menerima baik saran Hubab itu yang mengantarkan kemenangan gemilang dalam perang tersebut ${ }^{60}$

Setelah terjadinya perang Badar pada tahun dua Hijriyah, dan pasukan Islam mengalami kemenangan gemilang, mereka berhasil membawa sejumlah harta dan tawanan perang. Untuk menetapkan perlakuan terhadap tawanan tersebut, Nabi Muhammad mengadakan musyawarah dengan para sahabatnya. Dalam musyawarah itu muncul dua pendapat yang saling bertentangan. Abu Bakar berpendapat agar mereka dilepaskan saja dengan syarat membayar tebusan. Kemudian Nabi Muhammad bertanya kepada 'Umar ibn Khattab. Umar tidak setuju dengan usulan Abu Bakar, sebaliknya Umar mengusulkan agar mereka dibunuh saja. Kemudian Nabi mengambil keputusan tidak mengikuti pendapat Umar, tetapi lebih condong kepada pendapat Abu Bakar. Namun Nabi memberi kebebasan kepada para sahabat untuk memilih membunuh atau melepaskan para tawanan dan mengambil tebusan. Yang tidak mampu membayar tebusan diwajibkan mengajar penduduk Madinah. Namun kemudian turun wahyu yang tidak membenarkan pengambilan tebusan dari tawanan. ${ }^{61}$

\footnotetext{
${ }^{60}$ Lihat: secara lebih luas dalam Muhammad al-Ghazali, Sejarah Perjalanan Hidup Muhammad, terj. Kamdani, (Yogyakarta: Pustaka Pelajar, 2006), h. 292-293.

61Lihat: dalam Martin Lings, Muhammad, terj. Qamaruddin, (Jakarta: Serambi, 2007), h. 279-280; Hasbi Amiruddin, Konsep Negara Islam Menurut Fazlur Rahman, (Yogyakarta: UII Press, 2000), h. 55-56.
} 
Menjelang perang Uhud antara pihak Nabi di Madinah dan kaum Quraisy di Makkah, ada dua kemungkinan yang dihadapi: bertahan dalam kota Madinah atau berperang di luar kota. Nabi mengadakan musyawarah dengan kaum Muslim untuk menentukan pilihan. Nabi sendiri berpendapat bahwa lebih baik bertahan dalam kota. Tetapi rupanya mayoritas kaum Muslim menghendaki berperang dengan musuh di luar kota. Yang menarik menjelang perang ini adalah adanya musyawarah, waktu suara mayoritas mengalahkan bahkan suara Nabi, dan Nabi mengalah pada kehendak mayoritas. Meskipun dalam pertempuran itu kaum Muslim ternyata kalah, musyawarah juga yang menentukan. Ini berarti dalam musyawarah proses lebih penting dari hasil. Ini berarti juga bahwa suara minoritas betapapun kuat klaimnya atas kebenaran harus tunduk pada suara mayoritas. ${ }^{62}$

Ketika akan terjadi perang Khandaq, Nabi mengadakan musyawarah untuk membahasnya, sambil mengingat pengalaman pahit yang diperoleh pada perang Uhud. Beberapa sahabat lebih menyukai pertahanan berkubu di menara-menara dan tempat-tempat tinggi ketimbang menghadapi musuh di luar kota. Namun, gagasan ini tidak memadai, karena kabilah-kabilah Arab Mekah dan Madinah, serta golongan Yahudi berkolaborasi dengan puluhan ribu tentaranya tentu dapat menghancurkan kubu-kubu dan menara-menara tersebut lalu mengalahkan kaum Muslim. Karena itu, perlu diambil langkah-langkah meyakinkan untuk mencegah musuh memasuki Madinah.

Salman al-Farisi (orang Persia), yang mengetahui benar seni perang Iran, berkata, "Di Persia, bilamana rakyat terancam serangan musuh, mereka menggali parit di sekeliling kota untuk menghalangi majunya musuh. Karena itu, untuk menjaga bagian-bagian Madinah yang rentan, perlu digali parit untuk mencegah musuh. Bersamaan dengan itu, menara dan pos-pos penjagaan harus didirikan dekat tepian parit untuk pertahanan. Musuh harus dicegah agar tidak menyeberangi parit, dengan menembakkan panah dan melempari mereka dengan batu dari menara-menara dan pos tersebut". Saran Salman diterima dengan suara bulat. Nabi disertai beberapa orang, memeriksa bagian-bagian yang rentan dan memberi tanda di mana parit itu harus digali.63

\footnotetext{
62Disarikan dari Kuntowijoyo, Identitas Politik Umat Islam, (Bandung: Mizan, 1997), h. 96.

${ }^{63} J$ J'far Subhani, Ar-Risalah, terj. Muhammad Hasyim \& Meth Kieraha, (Jakarta: Lentera, 2004), h. 426-427; Bandingkan dengan Muhammad Husain Haikal, Sejarah Hidup Muhammad, terj. 'Ali Audah, (Jakarta: Litera AntarNusa, 1997), h. 344-345.
} 
Bercermin pada beberapa kasus di atas, tidak pelak lagi bahwa Nabi telah memberikan teladan yang sangat menakjubkan kepada umatnya sepanjang zaman mengenai keterbukaan, aspirasi umat, musyawarah, dan dialog konstruktif dalam memecahkan problem-problem sosial-politik. Prinsip-prinsip Islam yang bersifat terbuka-demokratis ini pun diteruskan oleh para sahabat empat ( $a l-$ al-khulafä'al-räshidīn).

Dengan alasan ini, tidak mengherankan jika sosiolog agama abad ke-20 Robert N. Bellah dalam karyanya Beyond Belief mengakui bahwa di bawah kepemimpinan Muhammad, masyarakat Arab telah melakukan lompatan jauh ke depan (remarkable leap forward) dalam kecanggihan sosial dan kapasitas politik. Ketika struktur etika yang terbentuk pada masa Nabi itu diperluas oleh para khalifah pertama untuk menyediakan prinsip penyusunan sebuah imperium dunia, hasilnya adalah suatu yang benar-benar modern (remarkably modern) untuk tempat dan masa itu. Masyarakat Islam awal dianggap modern dalam hal tingginya tingkat komitmen, keterlibatan, dan partisipasi yang diharapkan dari segenap lapisan masyarakat, serta modern pula dalam hal keterbukaan posisi pimpinannya untuk dinilai kemampuan mereka berdasarkan landasan universalistik dan melembagakan jabatan puncak yang tidak berdasarkan garis keturunan..$^{64}$

Pada titik ini, dengan meminjam perspektif Reza Aslan, setidaknya terdapat dua kelompok yang berbeda dalam memandang sejarah peradaban Madinah. Kelompok pertama memandang Madinah sebagai model pemerintahan yang paling ideal dan telah final. Tidak ada model lain yang dapat menggantikan kedudukan Madinah. Karena itu, bagi kelompok ini, kembali kepada model Madinah merupakan sebuah keniscayaan. Kelompok ini ingin menggunakan kekuasaan dan kewenangan yang tidak terbatas dalam menegakkan hukum Tuhan. Bahkan, mereka menganggap perang dan kekerasan sebagai warisan periode Madinah. Mereka melihat Madinah sebagai model yang sudah jadi sehingga dijadikan acuan, meskipun kita berjalan menuju ke depan.

Sebaliknya, kelompok kedua memandang Madinah sebagai model pemerintahan yang perlu dicontoh pada tataran nilai dan substansi yang membuka kemungkinan untuk dilakukan analogi dan adaptasi. Nabi memimpin penduduk

${ }^{64}$ Lihat: Robert N. Bellah, Beyond Belief, terj. Rudy harisyah Alam, (Jakarta: Paramadina, 2000), h. 210-211; Bandingkan dengan Nurcholish Madjid, Islam Doktrin \& Peradaban, Oakarta: Paramadina, 1996), h. 114, 121. 
Madinah dengan basis persaudaraan dan toleransi serta wibawa intelektual dan integritas. Kepemimpinan tersebut dituangkan dalam konstitusi yang dikenal dengan "Piagam Madinah". Konstitusi tersebut membuktikan Islam sebagai agama yang melindungi dan menjunjung tinggi kebhinekaan dan memiliki komitmen kuat untuk membangun perdamaian sebagai prasyarat kesejahteraan dan peradaban.

Karenanya Madinah merupakan salah satu model pemerintahan demokratis yang pernah ada dalam sejarah Islam yang untuk kontek hari ini diperlukan revitalisasi dan reinterpretasi. Menjadikan Madinah sebagai model bagi pengembangan demokrasi di dunia Islam merupakan sebuah keniscayaan. Kendatipun demikian diperlukan negosiasi, adaptasi, dan akulturasi dengan perkembangan zaman dan konteks kebudayaan lokal, terutama dalan rangka menjadikan Madinah sebagai jembatan dalam membangun masyarakat yang berkeadaban, bukan masyarakat yang berlandaskan supermasi militer dan kekerasan. ${ }^{65}$

Spirit inilah yang jauh-jauh hari telah disuarakan oleh filsuf sekaligus pujangga besar Pakistan, Muhammad Iqbal, bahwa dari momen historis Nabi dan para sahabat yang harus diambil adalah semangat dan respons kreatif mereka terhadap wahyu dan problematika faktual. ${ }^{66}$ Sebab jika infrastrukturnya secara legal formal yang hendak diambil, sistem yang dijalankan oleh Nabi dan sahabat empat belum mapan. Itulah sebabnya, dalam perspektif sosiologi agama, karena infrastrukturnya belum mapan, semangat keterbukaan, kebebasan, dan musyawarah yang bercorak demokratis itu kandas digantikan sistem monarki kembali setelah wafatnya sahabat 'Ali ra. ${ }^{67}$

Bahkan lebih jauh dalam penelitian Jamal al-Banna (adik kandung Hassan alBanna), pemerintahan tersebut belum bisa disebut sebagai negara dalam artian negara yang menganut sistem politik kebanyakan negara modern. Namun agar lebih safe, kata Jamal al-Banna sistem pemerintahan yang dijalankan Nabi lebih tepat disebut sebagai "negara Madinah" yang mempunyai latarbelakang kondisi unik sebagai eksperimen satu-satunya yang tidak akan terulang lagi. Sebab waktu

\footnotetext{
65Dikutip dari pengantar Komaruddin Hidayat dalam Zuhairi Misrawi, Madinah, Oakarta: Kompas, 2009), h. XV-xvi.

66Untuk lebih luasnya lihat dalam Robert D. Lee, Mencari Islam Autentik, terj. Ahmad Baiquni, (Bandung: Mizan 2000), h. 69-96.

${ }^{67}$ Robert N. Bellah, Beyond Belief, h. 211.
} 
itu belum mempunyai militer yang profesional, belum ada penjara permanen, belum ada lembaga kepolisian, dan juga belum mewajibkan pajak. Lebih jauh pimpinannya adalah seorang Nabi yang diutus dan dibimbing langsung oleh wahyu. Di sini kata Jamal al-Banna, peletakan dasar yang dilakukan Nabi merupakan dasar yang istimewa sekali dan satu-satunya, serta yang lain tidak bisa dianalogikan dengannya. ${ }^{68}$

\section{Kesimpulan}

Islam, baik secara teologis (kalämiyyah), dogmatis (fiqhiyyah), maupun sosiologis (ijtimāilyyah), selalu hadir dalam bentuk yang tidak pernah seragam. Sejak wafatnya Nabi, umat Islam selalu dihadapkan dengan beragamnya keyakinan ('aqïdah), baik mengenai ketuhanan, kenabian, wahyu, maupun persoalanpersoalan ghaybiyyat lainnya. Secara teologis, Islam selalu hadir dalam wajahnya yang beragam, dalam bentuk Murji'ah, Syi'ah, Khawarij, Mu'tazilah, maupun Ahl al-Sunnah.

Tradisi keilmuan fiqh juga memiliki keragaman wajah Islam yang tak ada tara bandingnya. Fiqh selalu memegang tradisi aktharu min qawlayn (lebih dari dua pendapat) yang berarti selalu ada kemungkinan kebenaran lain di luar kebenaran sendiri. Sedangkan secara sosiologis, lagi-lagi Islam juga hadir dalam wajahnya yang beragam. Karena itu, tepat sekali yang dikatakan Aziz Azmah, intelektual dari Suriah, "secara sosiologis kita tidak bisa bicara tentang satu Islam, tapi Islam-Islam".69

Oleh sebab itu, bukanlah sebuah kesalahan terminologis jika ada sebutan Islam India, Islam Nigerian, Islam Amerika, Islam Iran, Islam Pantai Gading, Islam Jepang, Islam Arab, Islam Turki, Islam Chad, Islam Brunei, Islam Prancis, Islam Indonesia dengan segala variasinya, dan seterusnya. Jangankan yang serba-besar itu, orang juga biasa menyebut Islam menurut paham Muhammadiyah, paham $\mathrm{NU}$, paham Persis, Islam paham garis keras, dan lain-lain.70

Jika perspektif ini diletakkan dalam konteks kehidupan politik Islam kontemporer, maka politik Islam tidak bisa dilepaskan dari sejarah Islam yang multi-

\footnotetext{
68Jamal al-Banna, Runtuhnya Negara Madinah, terj. Jamadi Sunardi \& Abdul Mufid, (Yogyakarta: Pilar Media, 2005), h. 3-49.

${ }^{69}$ Lutfi Assyaukanie, Islam Benar Vesus Islam Salah, (Depok: Kata Kita, 2007), h. 97-98.

${ }^{70} \mathrm{Ahmad}$ Syafii Maarif, Islam dalam Bingkai Keindonesiaan dan Kemanusiaan, (Bandung: Mizan, 2009), h. 19-20.
} 
interpretatif semacam itu. Pada sisi lain, hampir setiap Muslim percaya akan pentingnya prinsip-prinsip Islam dalam kehidupan politik. Pada saat yang sama, karena sifat Islam yang multiinterpretatif, tidak pernah ada pandangan tunggal mengenai bagaimana seharusnya Islam dan politik dikaitkan secara pas. Bahkan, sejauh yang dapat ditangkap dari perjalanan diskursus intelektual dan historis pemikiran dan praktik politik Islam, ada banyak pendapat yang berbeda beberapa bahkan saling bertentangan — mengenai hubungan yang sesuai antara Islam dan politik.71

Dan jika perspektif tersebut diturunkan dalam konstelasi Indonesia yang pluralistik, terutama dalam hal agama, pesan sentralnya adalah bagaimana menerjemahkan nilai-nilai Islam yang bersifat subjektif ke dalam tataran yang lebih objektif dan inklusif sehingga bisa memayungi semua agama yang berbeda satu sama lain. Semua komponen agama Islam sebaiknya diformulasikan terlebih dahulu ke dalam terminologi objektif yang dapat diterima oleh semua pihak. Konsep Tauhid misalnya, diterjemahkan dengan ketuhanan Yang Maha Esa, konsep shürā dengan musyawarah, dan konsep baldatun țayyibatun warabbun ghafür dengan negara kesejahteraan di bawah naungan Tuhan. Begitu pula konsep-konsep Islam lainnya seyogyanya dibingkai ke dalam istilah yang universal dan inklusivistik, seperti keadilan, persamaan antara manusia, kebebasan, kemakmuran, dan demokrasi. Seluruh istilah tersebut terdapat dalam ajaran prinsipil Islam namun bersifat inklusif dan mampu merangkul semua orang tanpa memandang golongan agama, suku, kelompok, warna kulit, dan bangsa.72 Dengan demikian, Islam benar-benar mampu mengimplementasikan misi utamanya sebagai rahmmatan li 'I-ālamīn, sebagai penebar kasih sayang Tuhan kepada seluruh makhluk-Nya walaupun tidak menggunakan simbol khilāfah atau negara Islam.[w]

\footnotetext{
${ }^{71}$ Bahtiar Effendy, Islam \& Negara..., h. 11.

${ }^{72}$ Dalam konteks Indonesia, ide-ide tersebut bisa ditemukan dalam pemikiran sejumlah cendekiawan dan Guru Bangsa kita. Lihat: Kuntowijoyo, Muslim Tanpa Masjid, (Bandung: Mizan, 2001), h. 140; Nurcholish Madjid, Dialog Keterbukaan, (Jakarta: Paramadina, 1998), h. 173-177; Abdurrahman Wahid, Islam dan Negara, (Jakarta: Grasindo, 1999), h. 53-158.
} 


\section{BIBLIOGRAFI}

al-Banna, Hasan, Majmū'at al-Rasāỉl, Beirut: Mu'assat al-Risālah, t.th.

al-Banna, Jamal, Runtuhnya Negara Madinah, terj. Jamadi Sunardi \& Abdul Mufid, Yogyakarta: Pilar Media, 2005.

al-Ghazali, Muhammad, Sejarah Perjalanan Hidup Muhammad, terj. Kamdani, Yogyakarta: Pustaka Pelajar, 2006.

Amiruddin, Hasbi, Konsep Negara Islam Menurut Fazlur Rahman, Yogyakarta: UII Press, 2000.

Armstrong, Karen, Berperang Demi Tuhan, terj. Satrio Wahono, dkk., Bandung: Mizan, 2002.

Armstrong, Karen, History of God, New York: Ballantine Books, 1993.

Armstrong, Karen, Muhammad, San Fracisco: Harper Collins, 1993.

Assyaukanie, Lutfi, Islam Benar Vesus Islam Salah, Depok: Kata Kita, 2007.

Azra, Azyumardi, Pergolakan politik Islam, Jakarta: Paramadina, 1996.

Bellah, Robert N., Beyond Belief, terj. Rudy harisyah Alam, Jakarta: Paramadina, 2000.

Binder, Leonard, Islam Liberal, terj. Imam Muttaqin, Yogyakarta: Pustaka Pelajar, 2001.

Effendy, Bahtiar, Teologi Baru Politik Islam, Yogyakarta: Galang Press, 2001.

Eickelman, Dale F. \& James Piscatori, Ekspresi Politik Muslim, terj. Rofik Suhud, Bandung: Mizan, 1998.

Esposito, John L., Masa Depan Islam, terj. Eva Y. Nukman \& Edi Wahyu, Bandung: Mizan, 2010.

Euben, Roxanne L., Musuh Dalam Cermin, terj. Satrio Wahono, Jakarta: Serambi, 2002.

Fadl, Khaled Abou, Selamatkan Islam Muslim Puritan, terj. Helmi Mustofa, Jakarta: Serambi, 2005.

Gulen, Fethullah, Versi Terdalam Kehidupan Rasul Allah Muhammad SAW, terj. Tri Wibowo Budi Santoso, Jakarta: Grafindo Persada, 2002. 
Haikal, Muhammad Husain, Sejarah Hidup Muhammad, terj. Ali Audah, Jakarta: Litera AntarNusa, 1997.

Hawwa, Said, Jundullah, terj. Hamim Thohari, dkk, Solo: Era Intermedia, 2002.

Hidayat, Komaruddin, "Pengantar", dalam Zuhairi Misrawi, Madinah, Jakarta: KOMPAS, 2009.

Hidayat, Komaruddin, Wahyu di Langit Wahyu di Bumi, Jakarta: Paramadina, 2003.

Hourani, Albert, Pemikiran Liberal di Dunia Arab, terj. Suparno, dkk., Bandung: Mizan, 2004.

Ibn Khaldun, 'Abd al-Rahman, Muqaddimah Ibn Khaldun, Beirut: Dar al-Kutub alIlmiyah, 2002.

Kaelan, Metode Penelitian Kualitatif bidang Filsafat, Yogyakarta: Paradigma, 2005.

Khan, Qomaruddin, Tentang Teori Politik Islam, terj. Taufik Adnan Amal, Bandung: Pustaka, 1987.

Kuntowijoyo, Identitas Politik Umat Islam, Bandung: Mizan, 1997.

Kuntowijoyo, Muslim Tanpa Masjid, Bandung: Mizan, 2001.

Lee, Robert D., Mencari Islam Autentik, terj. Ahmad Baiquni, Bandung: Mizan 2000.

Lings, Martin, Muhammad, terj. Qamaruddin, Jakarta: Serambi, 2007.

Maarif, Ahmad Syafii, Islam dalam Bingkai Keindonesiaan dan Kemanusiaan, Bandung: Mizan, 2009.

Madjid, Nurcholish, Dialog Keterbukaan, Jakarta: Paramadina, 1998.

Madjid, Nurcholish, Islam Doktrin \& Peradaban, Jakarta: Paramadina, 1996.

Mahmud, Halim, Wasāill al-Tarbiyyah 'inda Ikhwān al-Muslimīn, Kairo: Dar alWafa' li at-Tiba'ah wa al-Tauzi, 1993.

Pamuntjak, Laksmi, dkk., Tidak Ada Negara Islam, Jakarta: Djambatan, 2004.

Popper, Karl L., Open Society and Its Enemies, New York-London: Verso, 1981.

Pulungan, Suyuthi, Fiqh Siyasah, Jakarta: Grafindo Persada, 2002.

Quthb, Sayid, Karakteristik Konsepsi Islam, terj. Muzakkir, Bandung: Pustaka, 1990.

Rahman, Fazlur, "Islam and Political Action: Politics in the Service of Religion", dalam Nige Biggar, etal. (ed.), Cities of Gods: faith, Politics and Pluralism in Judaism, Christianity and Islam, New York: Greenwood Press, 1986. 
Rahman, Fazlur, Tema Pokok al-Qur'an, terj. Anas Mahyuddin, 1996.

al-Rais, Dhiya al-Din, Islam \& Khilafah, terj. Afif Mohammad, Bandung: Pustaka, 1985.

Rakhmat, Jalaluddin, Reformasi Sufistik, Bandung: Pustaka Hidayah, 1998.

al-Raziq, 'Ali ‘Abd, al-Islām wa Ușūl al-Hukm, terj. M. Zaid Su'di, Yogyakarta: Jendela, 2002.

Shihab, M. Quraish, Membumikan al-Qur'an, Bandung: Mizan, 1997.

Shihab, M. Quraish, Tafsir al-Mishbah, Vol. 2, Jakarta: Lentera Hati, 2000.

Sirry, Mun'im A. (ed.), Islam Liberalisme Demokrasi, Jakarta: Paramadina, 2002.

Sirry, Mun'im A. (ed.), Dilema Islam Dilema Demokrasi, Bekasi: Gugus Press, 2002.

Sjadzali, Munawir, Islam dan Tata Negara, Jakarta: UI Press, 1993.

Subhani, Ja'far, Ar-Risalah, terj. Muhammad Hasyim \& Meth Kieraha, Jakarta: Lentera, 2004.

Tanthowi, Pramono U. (ed.), Begawan Muhammadiyah, Jakarta: PSAP, 2005.

Tim PUSLIT IAIN Syarif Hidayatullah, Pendidikan Kewarganagaraan, Demokrasi, HAM dan Masyarakat Madani, Jakarta: IAIN Press, 2000.

Wahid, Abdurrahman, Islam dan Negara, Jakarta: Grasindo, 1999. 